\title{
SEC16A wt Allele
}

National Cancer Institute

\section{Source}

National Cancer Institute. SEC16A wt Allele. NCI Thesaurus. Code C101473.

Human SEC16A wild-type allele is located in the vicinity of 9q34.3 and is approximately 43 $\mathrm{kb}$ in length. This allele, which encodes protein transport protein Sec16A, plays a role in protein trafficking. 